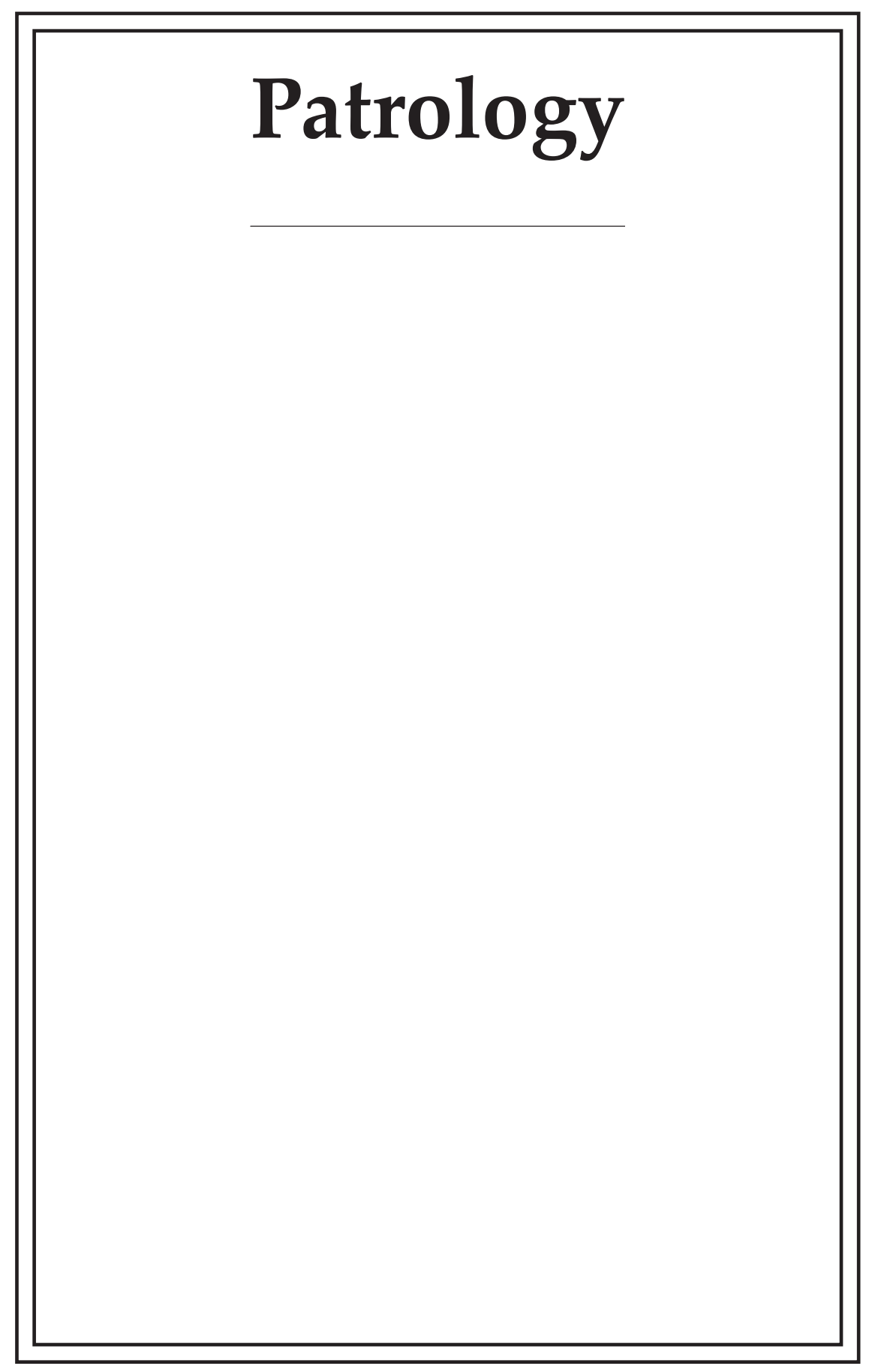

Downloaded from Brill.comఠ4/26/2023 02:30:32PM 
Dmitry Biriukov

Saint Petersburg State University of Aerospace Instrumentation

University of Padova

Saint Petersburg, Russia

dbirjuk@gmail.com

\section{HIERARCHIES OF BEINGS IN THE PATRISTIC THOUGHT: MAXIMUS THE CONFESSOR, JOHN OF DAMASCUS, AND THE PALAMITES}

1.

This article is a continuation of my previous study on the hierarchies of beings in Gregory of Nyssa and Dionysius the Areopagite, ${ }^{1}$ where I elaborate the materials presented in the paper dedicated to Gregory of Nyssa properly. ${ }^{2}$ For the sake of the following argument it would be useful to summarize the findings of my previous studies.

Two strategies of establishing the hierarchy of beings can be identified in Gregory of Nyssa: the strategy where the uncreated nature is at the summit, and the strategy where the existing ( $\tau \dot{\alpha}$ óv $\tau \alpha$ ) is at the top (or at the base, depending on the direction of viewing).

Thus, in the De opificio hominis, 8, and De anima et resurrectione (PG $46,60 \mathrm{AB})$ Gregory of Nyssa discussed the generic division, according to which the existing beings are divided into intellectual and corporeal beings. Gregory pointed out that corporeal beings are divided into those partaking in life and devoid of life; beings partaking in life are divided into those which have senses (or which are animate ${ }^{3}$ ) and those devoid of senses; and sensible beings are divided into rational and irrational beings. According to Gregory, such a division of natural

(1) D. BIRIUKOV, "Hierarchies of Beings in the Patristic Thought: Gregory of Nyssa and Dionysius the Areopagite", in: The Ways of Byzantine Philosophy, ed. M. KNEŽEvić, Alhambra, CA, Kosovska Mitrovica, 2014 (in print).

(2) D. BIRIUKOV, "Ascent of Nature from the Lower to the Perfect': Synthesis of Biblical and Logical-Philosophical Descriptions of the Order of Natural Beings in the De opificio hominis, 8 by Gregory of Nyssa" (in print).

(3) Cf. De opificio hominis, 8, PG, 44, col. 145.18-23 and 148.17-18. 
beings corresponds to the natural order of creation, described in the Book of Genesis.

In his Contra Eunomium Gregory of Nyssa makes the distinction within the intellectual realm and speaks about the division of beings into three natures: first, intellectual uncreated (divine) nature, second, intellectual created nature (angels and human souls), participating in the first in accordance with the goodness of will of the individuals belonging to that nature, and, third, sensible created nature. ${ }^{4}$ Speaking about participation of angels and humans in the divine nature according to the goodness of will (this presupposes that exactly holy, or defied people participate in the divine nature), Gregory uses the terminology opposing "according to participation" to "according to nature." Gregory refutes the notion according to which all created beings participate in the divine nature, as pantheistic. ${ }^{5}$

Exploring the origin of the generic division which is presented in Gregory of Nyssa in his De opificio hominis, 8 (the existing ( $\tau \dot{\alpha}$ öv $\tau \alpha)^{6}-$ corporeal ( $\sigma \omega \mu \alpha \tau \iota \kappa o ́ v) ~-~ l i v i n g ~(\zeta \omega \tau \iota k o ́ v) ~-~ s e n s i b l e / a n i m a t e ~(\alpha i \sigma \theta \eta-$

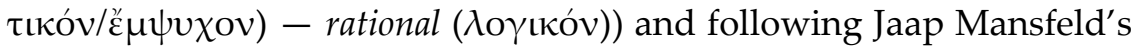

(4) Gregory of Nyssa, Contra Eunomium 1.1.270-277, sf. 1.1.295, in: Gregorii Nysseni opera, ed. W. JAEGER, vol. 1, Contra Eunomium Libri I et II, Leiden, 1960. In another passage of the same treatise Gregory speaks about division of beings into the uncreated and the created, and the division of created beings into the otherworldly and the sensible: Ibid., 4.100-101.

(5) Gregory of Nyssa, Contra Eunomium, 3.3.7.1-8.6, cf. 3.2.34-36, ed. JAEGER.

(6) T' $\dot{\alpha}$ óv $\tau \alpha$ understood here in the sense of "all that exists." In this regard, Gregory shows the influence of Stoic philosophy, where being-existing is also on the top or in the basis of the hierarchy of genera-species divisions (see: Stoicorum veterum fragmenta, ed. J. VON ARNIM, vol. 2, Leipzig, 1903, II 182) and at the same time it does also not claim for any ontological primacy. The link between the concept of "the existing" in Gregory and the Stoic context is confirmed by the usage of the term: in both cases it used the phrase $\tau \tilde{\omega} \nu$ óv $\tau \omega \nu$ (see in the Stoics: ibid., in Gregory: De opificio hominis 8, PG 44, col. 145.10, Contra Eunomium 1.1.270.1, 1.1.295.1, ed. JAEGER; Oratio catechetica magna, 6.10, in: Gregory of Nyssa, The catechetical oration, ed. J. SRAWLEY. Cambridge, 1903) what is understood in the sense of "...out of everything that exists," and in both cases this "existing" is divided into cor-

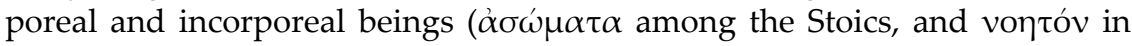
Gregory), although Gregory certainly understood the nature of this incorporeal in a completely different way than the Stoic philosophers. 
study on the genera-species divisions in Late Antiquity, ${ }^{7}$ we may distinguish the Aristotelian, the Platonic, and particularly prominent Stoic trends in the genera-species divisions proposed by Gregory of Nyssa. Relying on the observations of David Balas ${ }^{8}$ and Hubertus Drobner ${ }^{9}$ on the similarity in Gregory's levels of hierarchy and the socalled "Tree of Porphyry" (substance (oủoí $\alpha)$ - body $(\sigma \tilde{\omega} \mu \alpha)-$ ani-

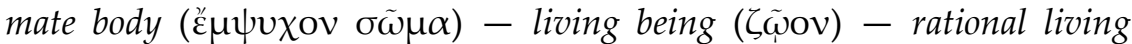

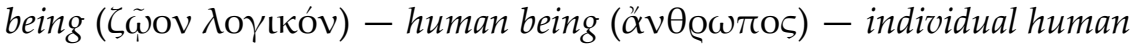
being $\left.{ }^{10}\right)$, it can be concluded that Porphyry made a direct influence on Gregory's reasoning. This being said, we need also to mention important discrepancies between the orders of levels in the two hierarchies, the point which was mostly neglected by previous scholars. The levels of living beings and animate beings in Gregory and Porphyry occupy the opposite places: in Gregory living beings precede animate beings, while in Porphyry animate beings precede living beings. Keeping in mind the context of De opificio hominis, 8, it can be proposed that the reason for Gregory's change in the order of levels in the genera-species hierarchy represented by the Tree of Porphyry was Gregory's desire to reconcile the logical/philosophical scheme of the division of beings conventional for his time, with the order of creating of natural beings, as it was described in the Bible, and with the logic of that order. ${ }^{11}$

The hierarchy of beings in Dionysius the Areopagite is fundamentally different than that of Gregory of Nyssa in terms of its structure. On the basis of Proclus' Neoplatonism, Dionysius introduced transcendental principles which corresponded to the levels of hierarchy, and in which the levels participated. Such a structural difference can be associated with the rethinking of the basic concept of partici-

(7) J. MANSFELD, "Substance, Being and Division in Middle Platonist and Later Aristotelian Contexts," in IDEM, Heresiography in context: Hippolytus' Elenchos as a source for Greek philosophy, Leiden, 1992, pp. 78-109.

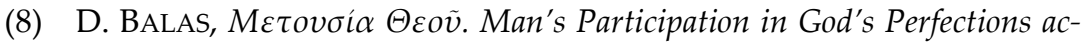
cording to St. Gregory of Nyssa, Rome, 1966, p. 36, n. 93.

(9) H. DROBNER, "Gregory Nyssa as Philosopher: De anima et resurrectione and De hominis opificio," Dionysius, 18 (2000), pp. 92-96.

(10) Porphyry, Isagoge 4: 15-27, in: Porphyrii isagoge et in Aristotelis categorias commentarium, ed. A. BUSSE, (Commentaria in Aristotelem Graeca, 4.1), Berlin, 1887.

(11) Cf. Gen. 1:11 and 1:20. 
pation, and, in particular, participation in the divine substance which occurred in the Patristic thought.

In this regard, we may distinguish three paradigms of participation used in the Patristic authors. ${ }^{12}$ According to the first paradigm, the participating entity was understood as different in nature from the participated entity, and the expression "according to participation" implies the opposition to that, which was "according to being" or "according to nature." This may be called the Platonic discourse of participation. According to the second paradigm, the opposite of the first, the concept of participation expressed a logical relationship between the genera-species predicables of varying degrees of generality: less general participates in more general, but not vice versa. Thus, "according to participation," in this paradigm is the same as "according to being," or "according to nature." This may be called the Aristotelian paradigm of participation. ${ }^{13}$ Finally, the third paradigm of participation, incorporating some elements of the Platonic and Aristotelian paradigms, was introduced in Byzantine Patristics by Dionysius the Areopagite. It implied the distinction between three aspects of participation: the non-participated, the participated, and the participating. ${ }^{14}$ This may be called the Neoplatonic paradigm of participation. Gregory of Nyssa, in the sense in which he said about participation of angels and humans in the divine nature and opposed "according to participation" to "according to nature," built his hierarchy following the Platonic paradigm, but for the authors who embraced the Neoplatonic paradigm of participation in their theological discourse and whose theological system entailed the aspect of utter non-particip-

(12) In most detail I concerned this topic in: Д. БИРЮКОВ, “Тема причастности Богу в святоотеческой традиции и у Никифора Григоры" [D. BIRIUKOV, "The topic of participation in God in the Patristic thought and in Nicephorus Gregoras"], in: Георгий Факрасис, Диспут свт. Григория Паламы с Григорой философом. Философские и богословские аспекты паламитских споров, пер. с древнегреч. Д. ПОСПЕАОВА, отв. ред. Д. БИРЮКОВ [Georgy Fakrasis, Disputation of St Gregory Palamas with Nicephorus Gregoras, a Philosopher. Philosophical and Theological Aspects of the Palamite controversy, tr. D. Pospelov, ed. D. BIRIUKOV], Москва, Святая гора Афон, 2009, с. 113-173.

(13) Cf. Aristotle, Topica, 121a10-15, 122b20-22.

(14) This triad of participation was introduced into philosophical language by Iamblichus (see the testimony of Proclus in his Commentary on the Timaeus, II, 105.16-28; 313.19-24) and was developed by Proclus among other philosophers. 
ation of the divinity or non-participation in the divine substance, it was quite natural to develop such a hierarchy which implied participation of created beings not in the divine substance, but in the higher transcendent principles - processions of God, His qualities or energies, as it was the cases with Dionysius the Areopagite, Maximus the Confessor, and Gregory Palamas, respectively.

If we further view the hierarchy of participating beings in Dionysius: beings ( $\tau \dot{\alpha}$ óv $\tau \alpha)$ - living beings $(\tau \dot{\alpha} \zeta \tilde{\omega} \nu \tau \alpha)$ - sensible beings

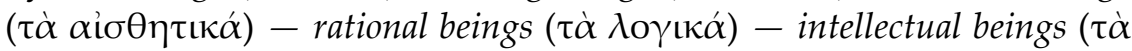
voe@ó $),{ }^{15}$ and examine what they participate in, we may see two types of principles, participated in by the levels in the hierarchy, namely, divine processions and principles with the prefix "self-."16 Dionysius writes about four primary divine names of Goodness, Being ( ò ôv), ${ }^{17}$ Life, and Wisdom as both associated with the divine processions and with the principles with the prefix "self-." Dionysius borrowed this sequence of names from the Neoplatonic tradition, where the doctrine of the triad (the tetrad) of (Goodness,) Being, Life, and Mind was developed. ${ }^{18}$ Under the influence of Dionysius, this triad would shape the development of the hierarchy of natural beings in some later major Patristic thinkers (as will be shown below).

The comparison of the Dionysian hierarchy of participating beings with the hierarchies of Gregory of Nyssa shows that although Gregory and Dionysius diverged in their understanding the hier-archy of beings as far as the transcendent principles corresponding to the levels in the hierarchy are concerned, there are common elements in the hierarchies, established by both authors. Thus there is a similarity in the sequence of levels: being - living beings - sensible beings - rational beings. It should be noted that the hierarchy of participating beings in Dionysius included the level of the sensible. Its presence is quite unexpected, since it does not seem to match Wisdom as the procession of God, which expands upon it, and in general falls out of the Dionysian order of the divine processions (Being, Life, Wisdom), participated

(15) De divinis nominibus, 5, 3, cf. 4,4 .

(16) See, especially, ibid., 5, 1-5; 11, 6.

(17) Sometimes instead of the notion of tò óv Dionysius used the no-

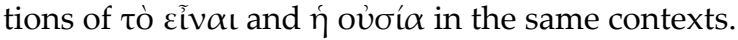

(18) See Proclus, Elements of Theology, 101, 102, and 8ff. In using this tetrad, Dionysius changed Mind into Wisdom, probably trying to bring his language closer to the Bible. 
in by the levels of hierarchy. ${ }^{19-20}$ At the same time, in the Dionysian hierarchy this level is located at the same place where it is found in the hierarchy of Gregory, between living beings and rational beings. This and the overall similarity in the sequence of levels in the hierarchies by Gregory and Dionysius, makes it possible to argue that the emergence of the level of sensible beings in the hierarchy of naturally participating beings of Dionysius was caused by his borrowing of the hierarchy of beings established by Gregory of Nyssa. Accordingly, Dionysius borrowed the level of sensible beings from the Gregorian hierarchy and included it into an appropriate place in his own hierarchy. In this way the Biblical order of natural beings through Gregory of Nyssa penetrates the Dionysian discourse and through Dionysius it becomes incorporated by the subsequent authors which will be discussed below.

\section{2.}

We should first turn to Maximus the Confessor who used the tetrad of Goodness, Being, Life, and Wisdom (or the triad of Being, Life, and Wisdom if the tetrad was taken without its first term), borrowed by Dionysius from the Platonists, and who discussed the hierarchy of beings in connection with the tetrad.

In the Ambiguum 24 which integrated the ascetic and the ontological trends in theology, Maximus discussed five tropoi of contemplation - a kind of theological categories: according to substance, movement, difference, mixing, and position. ${ }^{21}$ First three were intended for the knowledge of God and pointed to Him as, respectively, as the

(19) On the idea that the sensible corresponded to Wisdom, and on the order of the divine processions, see De divinis nominibus, 5,1 .

(20) It should be noted also that although the order of the participated divine names-processions was borrowed by Dionysius from Proclus, the Dionysian hierarchy of participation is not close to the hierarchy of participation in Proclus, which had the following form: living beings - vegetative beings - soulless bodies - matter (Platonic Theology, III, 6).

(21) The concept of five tropoi of contemplation, introduced by Maximus, echoes the Platonic tradition, more precisely, Plato's doctrine of five greatest classes of genera - being, identity, difference, rest, and motion (Sophist, 254D-255C); see the development of this doctrine of Plato in Plotinus (Enneads, VI, 2). See also J. DiLLON, "Philosophy and Theology in Proclus and Maximus the Confessor," Quaestiones Disputatae. A Journal of Philosophical Inquiry and Discussion, 2 (1-2) (2011), pp. 37-55. 
Creator, the Caretaker, and the Judge. Two last tropoi were of pedagogical nature: mixing referred to our ability of volition, and position corresponded to the stability of this volition's directionality towards the good. The saints, having connected position with movement, and mixing with difference, that is, reducing the five tropoi of contemplation to three, arrived at contemplation of substance, difference, and movement and saw the Cause (God) in the effects, contemplating it as

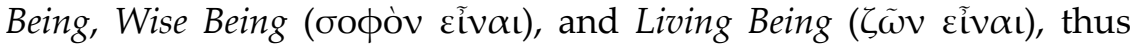
penetrating into the mystery of the tropoi of existence of the hyposteses in the Holy Trinity and learning a deifying doctrine of the Father, the Son and the Holy Spirit. ${ }^{22}$ We can speak about this triad as the triad of Being, Wisdom, and Life. Thus, in the Ambiguum 24 Maximus reproduced the Dionysian triad of Being, Life, and Wisdom in the form of a triad of Being, Wisdom, and Life, that is, rearranging the last two terms. Maximus correlated the members of the triad with persons of the Holy Trinity - the Father, the Son, and the Holy Spirit.

As it was noted earlier by Polycarp Sherwood, Maximus combined two triads: on the one hand, the Origenist-Evagrian triad of the Creator, Caretaker, and Judge, ${ }^{23}$ and, on the other hand, the Dionysian triad of Being, Life, and Wisdom, going back to Proclus. As likely sources for this passage in Maximus, Sherwood indicated the passages from the De divinis nominibus 5.2 and 5.3, where Dionysius discussed Goodness, Being, Life, and Wisdom. Dionysius, in turn, relied on the 101st and 102nd theorems from Proclus' Elements of Theology, which mentioned the triad of Being, Life, and Mind. According to Sherwood, Dionysius reworked the system of Proclus, changing the level of Mind from the Proclean structure into Wisdom, and adding a fourth element of Goodness. In this way, according to Sherwood, Maximus returned to the triadic structure of the system which had been present in Proclus (this is not entirely correct, since in the Elements of Theology, Proclus spoke also about Goodness as the supreme principle $\left.{ }^{24}\right)$, and, compared to the structure of Dionysius, he reordered Wisdom and Life based on the traditional Patristic sequence of

(22) Ambiguum, 24, in: PG, col. 1123A-1136C.

(23) See Evagrius of Pontus, Commentary on the Psalms, 138.16, in: PG, 12, col. 1161CD.

(24) Proclus, Elements of Theology, 8ff. Cf. E. PERL, Theophany: the Neoplatonic Philosophy of Dionysius the Areopagite, New York, 2007, p. 66. 
Persons - the Father - the Son - the Holy Spirit, referring Wisdom to the Son, and Life to the Holy Spirit (as to the Giver of Life). ${ }^{25}$

The Dionysian triad also found its place in Maximus the Confessor's Capita de caritate 3.24-25, where Maximus said that God, bringing intellectual and rational beings into existence, gave them four

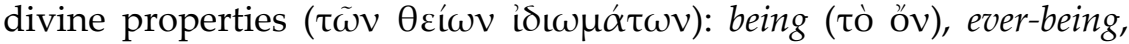
goodness, and wisdom, in which the rational and intellectual substance

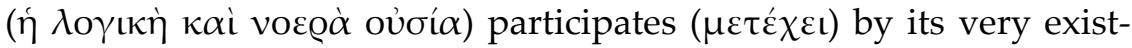
ence, by its capacity to exist in goodness, and by the grace of everbeing. First two divine properties were given to the substance, while last two properties were given to the gnomic ability, so created rational beings might become by participation that which God is by His nature. Here the topic of individual participation in the divine found its expression in Maximus. ${ }^{26}$ First two properties constituted the image of God in man, while the second two constituted the likeness of God in man. The terms "goodness," "being," and "wisdom" were used by Maximus for pointing both to the divine properties, and the properties bestowed by God upon the human beings.

In the Ambiguum 7 Maximus discussed the hierarchy of participating beings:

[We believe that]... the Word is shown and multiplied analogously ( $\alpha v \alpha \lambda \circ \gamma \dot{\alpha} \alpha v)$ to each in all [originating] from Him, and He is the head of all in Himself. Both being and rest correspond to him, and those which came into being are from Him, since [they] came into being; and depending on why [they] came into being, resting and moving, they participate in God ( $\mu \varepsilon \tau \dot{\varepsilon} \chi \varepsilon \iota ~ \Theta \varepsilon o \tilde{u})$. For all [created beings] because of their origin from God participate in God analo-

(25) P. SHERWOOD, "Introduction," in: Maximus the Confessor: The Ascetic Life. The Four Centuries on Charity, trans. by P. SHERWOOD, O.S.B., S.T.D. (Ancient Christian Writers), Mahwah, N.J., 1955, pp. 40-41. These observations of Sherwood were reproduced by the subsequent scholars; see L. THUNBERG, Microcosm and Mediator. The Theological Anthropology of Maximus the Confessor, Lund, 1965, pp. 129-130. Thunberg claims (p. 130) that according to Sherwood, Maximus the Confessor combined the Dionysian levels of Wisdom and Goodness, whereas in fact, Sherwood discovered that Maximus changed the order of the Dionysian levels of Wisdom and Life; L. THUNBERG, Man and the Cosmos: The Vision of Maximus the Confessor, Crestwood, N.Y., 1984, p. 46; J. Dillon, "Philosophy and Theology."

(26) On the subject, see also for instance Ambiguum, 42, in: PG, 91, col. 1329AB. 
gously ( $\dot{\alpha} v \alpha \lambda o ́ \gamma \omega \varsigma$ ), either according to mind (voũv), or reason

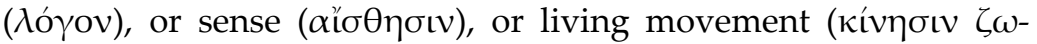

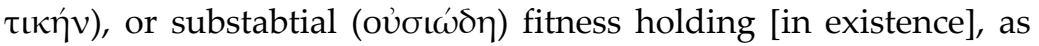
the great revealer of God Dionysius the Areopagite thinks. ${ }^{27}$

In the passage Maximus speaks about a hierarchy of natural abilities of created beings, through which every created being participates in God in accordance with its nature to a greater or lesser extent compared to other natural beings. Maximus mentions natural participation in God according to the abilities of substantial fitness (of being), life, sense, reason, and mind. Due to the principle of analogy, these natural abilities constitute a hierarchy from the level of being to the level of mind, increasing in the ontological sense. The listing and order of these natural abilities as formulated by Maximus, coincides with the hierarchically organized order of natural abilities of created beings, corresponding to the divine procession of Being, Life, and Wisdom, mentioned by Dionysius in the De divinis nominibus 5, 3 and 4, 4, where Dionysius wrote about beings - living beings - sensible beings - rational beings - intellectual beings. Clearly, Maximus must have adopted this system from Dionysius. ${ }^{28}$

We may note that while Dionysius articulated the principle, according to which each successive level of participating hierarchy included the previous levels, what means that the possession of each subsequent natural ability required possession of the previous abilities as well as the corresponding participations (De divinis nominibus, 5,3), Maximus did not explicitly elaborate on that point here.

Thus, the hierarchy of naturally participating beings in Maximus goes back through Dionysius, on the one hand, to the Neoplatonic

(27) Ambiguum, 7, in: $P G, 91$, col. 1080AB.

(28) Moreover, in this passage from Ambiguum, 7, Maximus combined several Dionysian concepts related to the hierarchy of participating beings, which surface in different passages of De divinis nominibus of Dionysius. These are the notions of commeasurement ( $\dot{\alpha} v \alpha \lambda$ o $\gamma^{\prime} \alpha$, see De divinis nominibus, 1, 2: 110.13; 4, 1: 144.5; 4, 33: 178.17, in: Pseudo-Dionysius Areopagita, De divinis nominibus, ed. B. R. SUCHLA (PTS, 33), Berlin, 1990; on this concept in Dionysius see A. Golitizin, Et Introibo Ad Altare Dei: The Mystagogy of Dionysius Areopagita: with Special Reference to Its Predecessors in the Eastern Christian Tradition, Thessalonike, 1994, p. 86ff.) and fitness (غ̇ De divinis nominibus, 1, 5: 118.1; 4, 4: 147.17, 148.18; 9, 10: 214.4, ed. SUCHLA) implying the concept of the measure of natural participation for various kinds of created beings. 
triad of Being, Life, and Mind, and, on the other hand, in respect to the level ensuring natural participation according to sense - to the teaching of Gregory of Nyssa and through him to the Biblical cosmogonic order of natural beings.

We may ask whether Maximus, just like Dionysius, shows the correspondence between the order of levels in the participating hierarchy and the order of the entities, participated in by the levels. In other words, the question is whether Maximus has an equivalent of the divine processions appearing in the system of Dionysius, which correspond to the Neoplatonic triad (tetrad) of (Goodness), Being, Life, and Mind, and which are participated in by the levels of the hierarchy of beings.

In the passage quote above, ${ }^{29}$ Maximus the Confessor speaks about direct participation of created beings in God according to their natural abilities. The immediate context of the passage as well as of other texts of Maximus indicates that according to him, the logoi from before the ages, by which God brought creation into being, correspond to the kinds of created beings. In Ambiguum 7, Maximus mentioned the logoi of angels, powers and entities of the heavenly world, the logoi of humans, and the logoi of all that exists. ${ }^{30}$

We may try to find out specific meaning of what those participating natural abilities participate in, bearing in mind the Neoplatonic triad (tetrad) of (Goodness), Being, Life, and Mind, which genetically, by mediation of Dionysius the Areopagite, influenced Maximus' teaching on the hierarchy of participating natural abilities. In fact, as it is evident from the foregoing, Maximus sometimes used the notions of the participated Goodness, Being, Life, and Mind in his theological language.

Well, Being, Life, and Mind cannot be viewed as principles participated in by the created beings, when Maximus used the terms for designating the Persons of the Holy Trinity, as he did in Ambiguum 24, since the Persons of the Holy Trinity cannot be participated in by the creation. However, in the Capita de caritate 3.24-25 in the context of the triad of Goodness, Being, and Wisdom borrowed from Dionysius, Maximus speaks about Being (and ever-being) as simultaneously a property of God and something which human beings possess by nature due to their natural participation in God. We may also recall a

(29) Ambiguum, 7, in: PG 91, col. 1080AB.

(30) Ibid., col. 1080AC. 
well-known passage from the Capita Theologia et Oeconomiae 1.48, where Maximus speaks about participated timeless works of God ( $\tau \dot{\alpha}$ ह้o $\gamma \alpha$ ), which are Goodness, Life, Immortality, Simplicity, Immutability, and Limitlessness contemplated around God. Among these properties, Goodness and Life are also included in the Dionysian tetrad.

Thus, we can say that Maximus did not elaborate the doctrine of the supreme principles participated in by the levels in the hierarchy of naturally participating beings, corresponding to the Neoplatonic triad (tetrad) of (Goodness), Being, Life, and Mind, in great detail. Nevertheless, we may speak of Being and Life as such principles - divine properties or divine works - participated in by the corresponding natural abilities of created beings. As opposed to Dionysius, the participated Wisdom which Maximus mentioned in the Capita de caritate 3.25 , corresponds not to a ability of human beings but to an inclination of will. Therefore we cannot mention it among the principles included in the Neoplatonic triad and naturally participated in by the created beings.

\section{3.}

Next we should discuss the Neoplatonic triad of Being, Life, and Mind in the natural hierarchy of participating beings in John of Damascus who addresses the topic of participation in his Exact Exposition of the Orthodox Faith in the following way:

Because of the exceedingly great wealth of His goodness, the good, all-good, and exceedingly good God, who is all goodness, did not rest content that the Good, or His nature, should just be and not be participated in ( $\mu \varepsilon \tau \varepsilon \chi o ́ \mu \varepsilon v o v)$ by anything. For this reason, He first made the intellectual and heavenly powers ( $\tau \dot{\alpha} \varsigma$

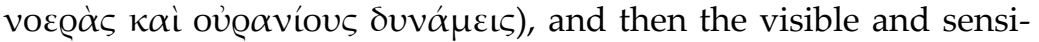
ble world, and then, finally, man of the intellectual and the sensi-

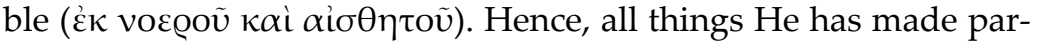

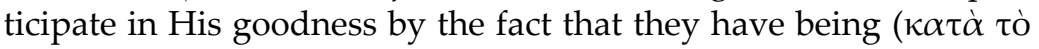

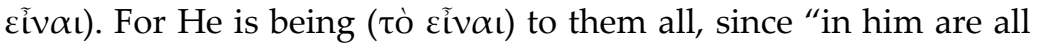
things," ${ }^{\prime 11}$ not only because He has brought them from nothing into being, but because it is by His operation that all things He made are kept in existence and held together. Living beings ( $\tau \dot{\alpha} \zeta \tilde{\omega} \alpha)$, however, participate more abundantly, because they participate

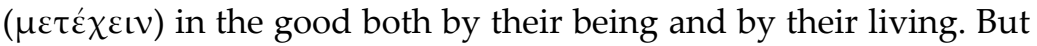

(31) Rom. 11:36. 
rational beings ( $\tau \dot{\alpha} \lambda \mathrm{o} \gamma \iota \kappa \dot{\alpha})$, while they participate in the good in the aforementioned ways, do so still more by their very rationality

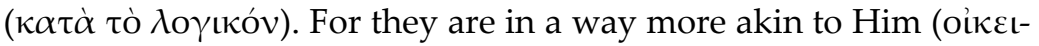
ó $\varepsilon £ \alpha)$, even though He is, of course, immeasurably superior. ${ }^{32}$

John of Damascus followed what can be called the Platonic paradigm of participation ${ }^{33}$ - the paradigm according to which something participating in the nature of other being did not become of the same nature as the participated entity by virtue of participation. John of Damascus stated that all created beings in their existence participate in God as Goodness that is His nature. ${ }^{34}$ Developing this idea, John of Damascus described how living and rational beings participated in God through their natural abilities in such a way that each subsequent ability and participation incorporated the preceding abilities. Living beings participated in God through life and being; and rational beings participated in God through reason, life, and being. Here we may clearly discern the Neoplatonic triad of Being, Life, and Mind.

(32) Expositio fidei, 4 XIII (86), 2-14, in: Die Schriften des Johannes von Damaskos, ed. B. KOTTER (PTS, 7; 12; 17; 22; 29), Berlin, 1969, 1973, 1975, 1981, 1988; transl. by F. H. CHASE, in: Saint John of Damascus, Writings (The Fathers of Church. A new translation), New York, 1958, p. 354, slightly revised by me.

(33) In general in his writings John of Damascus used all possible paradigms of participation of his time as applied to substance (nature) - the Platonic, Aristotelian, and Neoplatonic paradigm. In addition to the above citation, the Platonic paradigm is manifested, for example, in the Apologetic Treatises against Those Who Calumniate Divine Images, 3.33. The Aristotelian paradigm appears in the De duabus in Christo voluntatibus, 7; the Neoplatonic paradigm is used in De duabus in Christo voluntatibus, 11:9-10 (in Die Schriften des Johannes von Damaskos, ed. B. KOTTER), and in the Expositio fidei, 7 (51). We may point to some inconsistencies in the way John of Damascus used all three paradigms of participation in substance. Thus, in the Apologetic Treatises, 3.33, John of Damascus speaks about participation of saints in the divine substance, whereas in De duabus in Christo voluntatibus, 11:9-10, ed. KOTTER, he mentions that the divine substance is non-participated.

(34) It seems that we do not have reasons to think that John of Damascus used the concept of nature in the technical sense as the common substance of the hypostases of the Holy Trinity, speaking here about Goodness, participated in by the natural species as about something constituting the nature of God. More likely, John of Damascus meant that Goodness was an essential property of Godhead. 
Compared to the lists of participating natural abilities established by Dionysius the Areopagite and Maximus the Confessor, the levels of intellectual and sensible as individual entities are absent in John of Damascus. It seems that John's train of thought in the passage sug-

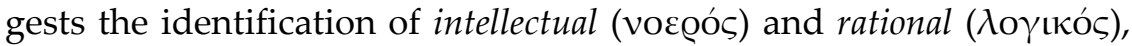
since at first John of Damascus speaks about God's creation of intellectual powers and human beings who possessed an intellectual principle among other faculties. Then John follows up describing rational beings $(\tau \dot{\alpha} \lambda \mathrm{o}\langle\kappa \dot{\alpha})$ as participating in God according to rationality and describes them as the most closely participating in God, obviously implying that rational beings are the bearers of the intellectual principle. The fact that John of Damascus did not mention the level of the sensible in his natural hierarchy of participating beings can be explained by his borrowing of the hierarchy from Dionysius the Areopagite. However, in building up his hierarchy and enumerating its levels, John of Damascus must here have relied not on the order of levels in the Dionysus hierarchy of participating beings, which contained the level of the sensible, ${ }^{35}$ but on the Dionysian description of the participated processions of God: Goodness, Being, Life, and Wisdom. ${ }^{36}$ At the same time, in accordance with the standard name of the corresponding level in the hierarchy of the participating in Dionysius and Maximus, John changed wisdom into reason.

The proximity of John of Damascus to Dionysius the Areopagite also finds its expression in John's statement that the beings, richest in possession of natural abilities, allowing them to participate in God (that is, rational beings), are the most akin to God. Dionysius expressed the same idea when he said concerning the hierarchy of participating beings that the beings which had the largest number of natural perfections - intellectual beings - are the closest to God. ${ }^{37}$

Finally it should be noted that John of Damascus does not seem to have a doctrine of principles participated in by the levels of natural hierarchy of beings; he speaks about participation of beings through their natural abilities directly in God or in natural divine Goodness, but not in some higher realities like some universals-before-things corresponding to the natural abilities of created beings, as it was in the case with Dionysius and Maximus.

(35) De divinis nominibus, 5, 3.

(36) Ibid., 5, 1-2.

(37) Ibid., 5, 3: ed. SuCHLA, p. 182.3-4. 
4.

At this point we should discuss the hierarchy of participating beings in Gregory Palamas. I suggest that this subject started to be actively discussed in the Palamite controversy in connection with the doctrine of the anti-Palamite Gregory Akindynos. Unlike Barlaam of Calabria, his predecessor in the polemics with the Palamite doctrine on the distinction between substance and uncreated energies in $\operatorname{God}^{38}$ and on the divinity of the Tabor light defended by Palamas, Akindynos taught about participation in the divine substance. The fact that Akindynos held this view even before the summer of 1341 is testified by a passage from the Short History of How the Evil Heresy of Barlaam and Akindynos Originated written by the monk David Disypatos, a friend of Gregory Palamas. That passage from the manuscript Oxon. Misc. gr. 120, was not used by the editor of the Short History Manuel Candal; ${ }^{39}$ it was discovered by Richard Browning and was published in his edition of the Poem against Akindynos by David Disypatos. According to the passage, beings of the created order - inanimate, irrational, and rational - participate in divine substance:

$<\ldots>$ Fearing to end up having the same fate as Barlaam, for he preached the same blasphemous doctrine, [Akindynos] resorted to a trick - he would not answer directly. <...> He admitted only substance to be incorruptible, and therefore he presented divine substance as participated and visible, $<\ldots>$ and participated in not only by rational creatures, but also by the irrational, and even inanimate $<\ldots .$. . $^{40}$

We can see from this passage that it describes the events of the time between the Councils of Constantinople in June and July 1341, when Barlaam had already been condemned ${ }^{41}$ (this, apparently, was "the fate of Barlaam" resulting from his preaching of "blasphemous doc-

(38) See the evidence that the doctrine of participation in the divine substance was inacceptable for Barlaam in the Short History of David Disypatos (M. CANDAL, "Orígen ideológico del palamismo en un documento de David Disípato," OCP, 15 (1949), pp. 39-41); the same is mentioned in the acts of the Council of Constantinople in June 1341.

(39) M. CANDAL, "Orígen ideológico del palamismo."

(40) R. BRowning, "David Dishypatos' Poem on Akindynos," Byzantion, 25-27 (1955-1957), p. 744.

(41) That is, condemned at the Council of Constantinople on June 10, 1341. 
trine," mentioned in the passage) while Akindynos was not condemned yet. ${ }^{42}$ The testimony that Akindynos taught about participation of all creation in the divine substance seems to be trustworthy since it fits the theological doctrine of Akindynos attested in his other texts. ${ }^{43}$ On the other hand, the accusation that the divine substance according to Akindynos was visible, seems to merely represent a rhetorical device of the narrator.

In the opposition to the belief of Akindynos that created beings in the measure of their natural abilities (which constituted a certain hierarchy) participated in the divine substance, Gregory Palamas developed the doctrine that created beings participated in God through participation in uncreated divine energies, while the divine substance could not be participated in by anything created. At the same time, while the participation paradigm offered by Akindynos did not employ a conceptual framework making it possible to distinguish between the modes of participation of the holy men and of the rest of the humans in God, Gregory Palamas emphasized the distinction between the natural mode of participation in God for all beings, and the supernatural participation of the deified people.

For this reason, Palamas distinguished between two kinds of uncreated divine energies: on the one hand, there are the creating energies, and the other hand, the energy of deification. Various creating ener-

(42) Akindynos was condemned at the Council of Constantinople, summoned in July, 1341.

(43) Thus, in his treatise the Dialogue between an Orthodox and a Barlaamite, 3.91, in: Gregorii Acindyni Refutationes duae operas Gregorii Palamae cui titulus Dialogus inter orthodoxum et Barlaamitam, nunc primum editae curante J. NADAl CAÑElLAS (CCSG, 31), Brepols, Turnhout, 1995, pp. 305-306, Akindynos discussed how participation in substance could be understood. After mentioning an interpretation, inappropriate in the theological context, which implied that the nature of the participated being was assumed by the participating being, he mentioned the appropriate understanding of participation in substance in such a way as the body participated in the soul, while each of them did not assume the nature of the other; thus the soul was both by its nature participated and unparticipated in by the body. Likewise, according to substance God was both participated and unparticipated. Similar position concerning participation in the divine substance was expressed by Nicephorus Grigoras, the next major representative of the anti-Palamite movement after Akindynos (see Nicephorus Grigoras, Antirrheticus I, 2.1, in: Nikephoros Gregoras Antirrhetika I, Einl., Textausgabe, Übers. und Anm. von H.-V. BEYER (Wiener Byzantinische Studien, XII), Wien, 1976, p. 231.17-20). 
gies are participated in by all created beings depending on their place in the hierarchy of natural abilities; ${ }^{44}$ deifying energy is supernaturally participated in by the deified humans and the angelic powers which are capable of participation, in addition to natural participation in the creating energies.

Gregory Palamas developed his doctrine of the hierarchy of participating beings in the treatises On the divine union and distinction (the summer of 1341), the Dialogue between an Orthodox and a Barlaamite (the autumn of 1341), On the divine and deifying participation (the winter of 1341/1342), and in the Antirrhetikoi against Akindynos (13421345). ${ }^{45}$

Speaking about the hierarchy of natural abilities, Palamas distinguished - in the descending measure of generality - natural participation of the following types: existential, living, sensible, rational, intellectual (or wisdom-like $e^{46}$ ), as well as spiritual (for angelic powers ${ }^{47}$ ).

(44) When Doru Costache discusses the kinds of participation of created beings in Palamas' On the divine and deifying participation, 11, he seems to

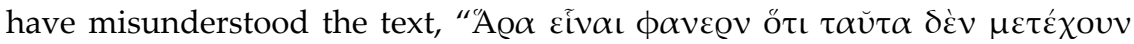

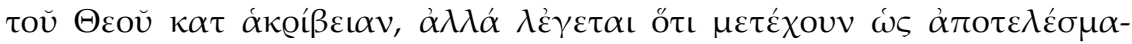

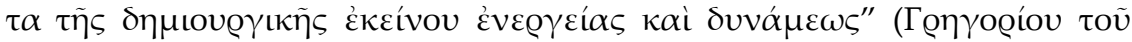

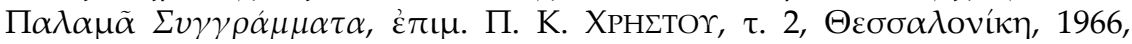
p. 237:10-13) in such a way that according to him the kinds of created beings participated in the effect of the creating divine energies (and not in the creating divine energies themselves): “...whilst the saints experience the divine life as an immediate and deifying participation, all other beings are only capable of a providential or mediated participation in the 'effect' ( $\alpha \pi 0-$

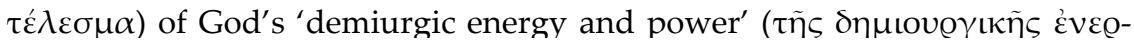
$\gamma \varepsilon \dot{c} \alpha \varsigma \kappa \alpha i$ $\delta v v \alpha \dot{\mu} \mu \omega \varsigma)$ )" (D. CostaCHE, "Experiencing the Divine Life: Levels of Participation in St Gregory Palamas' On the Divine and Deifying Participation," Phronesis, $26: 1$ (2011), p. 16). Clearly, however, the notion of $\alpha \pi 0-$ $\tau \varepsilon \dot{\lambda} \varepsilon \sigma \mu \alpha$ is associated here not with divine energies, but with created beings; the passage means that created beings participate in God, being themselves the "products" ( $\dot{\alpha} \pi 0 \tau \varepsilon \dot{\varepsilon} \lambda \varepsilon \sigma \mu \alpha)$ of His creating energy and power.

(45) Palamas also briefly mentions the kinds of natural participation of created beings in the divine creating energies in the Triads 3.2.11, and in the Capita 150, 87, 89, 91 (in connection with the doctrine of Dionysius).

(46) Gregory Palamas speaks of wisdom-giving energy which implies the ability of wisdom participating in it, instead of the notion of the intellectual, usual for him in this context, in the Fifth Antirrheticus against Akindynos,

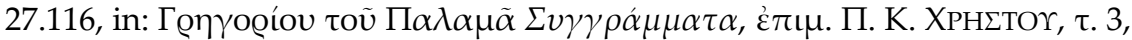
$\Theta \varepsilon \sigma \sigma \alpha \lambda$ ovík $\eta$, 1970, p. 23. Obviously Palamas depends here on the name of 
A specific creating divine energy - substance-creating, life-giving, wisdom-giving, etc. - corresponds to each of these abilities. A being which possesses the abilities, participates in the energies. ${ }^{48}$ Almost everywhere, where Palamas used the concept of the hierarchy of naturally participating beings, he also mentioned participation of people "who live in a divine way" in the deifying energy. ${ }^{49}$

Palamas argued that according to its nature, the created being could possess different kinds of natural participation. In On the divine union and distinction, 16, Palamas said that all created beings participated in God in virtue of their existence. Another kind of created beings combined existential, living, and sensible natural abilities (probably Palamas had animals in mind), as well as the corresponding participations. Human beings combined existential, living, sensible, rational, and intellectual abilities, as well as the ways of participating in God. Thus, following the Dionysian paradigm, Palamas taught that possession of each subsequent natural ability (within the above order of abilities), corresponding to the participation in a certain divine energy, entailed the possession of the previous abilities and the corresponding participations. ${ }^{50}$ One can say that in this respect the kinds of created beings - the bearers of the corresponding kinds of natural participations - constituted the hierarchy.

Following Dionysius the Areopagite, ${ }^{51}$ Palamas also argued that God was fully participated in by the creation, whereas intellectual

the corresponding divine procession in Dionysius the Areopagite (De divinis nominibus, 2, 5: p. 129.1, ed. SuCHLA).

(47) Palamas clearly speaks of this kind of natural participation only in the Dialogue between an Orthodox and a Barlaamite, 46-47. The fact, that he mentions angelic powers as a kind of created beings corresponding to the highest level in the hierarchy of the participating beings, shows the influence of Dionysius the Areopagite (De divinis nominibus, 5, 3). According to the Dionysian hierarchy of participating beings, angelic powers occupy the same place.

(48) Fifth Antirrheticus against Akindynos, 27.116.

(49) On the divine and deifying participation, 11: ed. ХРНЕTOҮ, p. 147.3.

(50) It is not entirely clear how this works in the case of angelic powers, corresponding to the highest level in the hierarchy of natural abilities (spiritual), since the nature of angels, obviously, does not include the preceding perfections of the hierarchy.

(51) De divinis nominibus, 2, 5. 
created beings could participate in Him fully or partly ${ }^{52}$ depending on the disposition of will. On the part of God, the completeness of natural participation in Him by the created beings did not depend on the type or number of the kinds of this participation, but natural participation in God at least in one respect implied participation in the entire divinity. ${ }^{53}$

Gregory also followed the Areopagite while speaking about the order of levels in the hierarchy of naturally participating beings. Levels and their order, listed by Palamas, are the following: existential living - sensible - rational - intellectual / wisdom-like - spiritual. In general they correspond to the hierarchy of Dionysius: beings - living beings - sensible beings - rational beings - intellectual beings, and therefore the hierarchy of natural beings in Gregory must have gone back through the Areopagite, on the one hand, to the Neoplatonic triad of Being, Life, and Mind, and, on the other hand (in respect to the level of the sensible, located between living beings and rational beings), to the hierarchy built by Gregory of Nyssa, and through it to the Biblical cosmogonic order of natural beings.

However, there are certain differences between the hierarchies of naturally participating beings developed by Gregory Palamas and Dionysius the Areopagite.

Thus, Palamas' list of natural abilities through which created beings participate in God, included the level of spiritual ( $\pi v \varepsilon v \mu \alpha \tau \iota \kappa o ́ s)$, corresponding to a natural participation, typical for the angelic powers, while in Dionysius angelic powers participated in God through intellectual ability. This means that Gregory Palamas partly shifted natural abilities in relation to the kinds of created beings which possessed them, compared to Dionysius: in the Dionysian hierarchy of naturally participating beings, intellectual ability was typical for the angelic (intellectual) powers, while rational ability was typical for the humans. ${ }^{54}$ In Palamas, intellectual ability was typical for the humans, while spiritual natural ability was typical for the angelic powers.

Another difference between Dionysius the Areopagite and Gregory Palamas is that the hierarchy of naturally participating beings in Gregory is strictly connected with the idea of supernatural participa-

(52) Cf. Fifth Antirrheticus against Akindynos, 27.115; Dialogue between an Orthodox and a Barlaamite 45-47.

(53) Fifth Antirrheticus against Akindynos, 27.116: 20-21, ed. ХРНгтОҮ.

(54) De divinis nominibus 5, 3; E. PERL, Theophany, pp. 70-71. 
tion. We may say that the very subject of the hierarchy of naturally participating beings appears in Palamas to clarify the difference of deification as supernatural participation in God and natural participation of all beings in God. Therefore, the discussion about the hierarchy of naturally participating beings in Gregory Palamas is almost always related to and emphasized by the doctrine of the supernatural participation of the deified people in God. This means that the highest element in Palamas' hierarchy of participation for the created beings - not only natural participation, but also supernatural - is the deifying participation corresponding to the deifying divine energy. ${ }^{55}$

At the same time, although Dionysius speaks about the principle of Self-Divinity or Self-Deification, as well as about deified beings, corresponding to $i^{56}{ }^{56}$ he mentions this principle among other principles with the prefix "Self-," without emphasizing it or incorporating it into the hierarchy of participating beings. The hierarchies of participation, found in Maximus the Confessor and John of Damascus as well do not employ the element responsible for deification.

Besides this, while both Dionysius and Maximus developed the discourse of individual participation in God, fundamental for Palamas' doctrine of supernatural participation, these authors did not associate it with the hierarchy of participating beings.

In the authors, preceding Gregory Palamas, which we briefly viewed, the topic of deification was treated in the context of the hierarchy of beings only by Gregory of Nyssa, but from an entirely different viewpoint in regards to the mechanism and the structure of the hierarchy than that of Palamas. We should point to the contrasting conceptual frameworks used by Gregory of Nyssa and Gregory Palamas for indicating the concept of deifying participation in God in the context of the hierarchy of participating beings. Gregory of Nyssa used the concept of participation in the divine nature, ${ }^{57}$ while this concept was forbidden for Palamas, ${ }^{58}$ and deifying participation in

(55) In particular, see the Fifth Antirrheticus against Akindynos, 27.116.

(56) De divinis nominibus, 11, 6.

(57) See Contra Eunomium, 1.1.270-277, ed. JAEGER; specifically on the participation of intellectual created beings in uncreated divine nature depending on the goodness of will, see ibid., 1.1.274.1-4.

(58) The doctrine that divine substance cannot at all be participated in by the created beings is a throughline in the texts of Palamas, and he discussed this issue very often. However, there are isolated instances when Gregory softens this attitude: in the in the 13th chapter of the dialogue 
Palamas' theological system was understood as participation not in the divine nature, but in the uncreated energy of God. This difference is associated with the opposite paradigms of participation used by Gregory of Nyssa and Gregory Palamas. Gregory of Nyssa used the Platonic paradigm of participation when he spoke about participation of holy men in the divine nature. The Platonic paradigm implies that something, participating in the nature of something else, does not become of the same nature by virtue of participation. In his theological language, Gregory Palamas used the Neoplatonic paradigm of participation introduced in the Patristic thought by the Areopagite, which implied a distinction of the unparticipated and the participated in God. Following Maximus the Confessor, Gregory Palamas related the unparticipation to the divine substance. Thereby the system of Gregory Palamas entailed deifying participation in God as participation in the uncreated divine energy, and not in the divine nature, as was the case in Gregory of Nyssa.

Thus, a substantial point in the teaching of Gregory Palamas on the hierarchy of participating beings is his position on what the hier-

Theophanes he says in the person of one of the interlocutors (Theophanes), that although the substance of God cannot be participated in, it is nevertheless somehow participated (ed. ХРНгTOr, p. 238.7-10), and in the 17th chapter, Palamas says that the divine nature is participated in, although not in itself, but through its energies (ed. ХРНгтОҮ, p. 243.20-24); see also David Disypatos, Poem against Akindynos, pp. 447-448, in ed.: R. BROWNING, "David Dishypatos' Poem on Akindynos," Byzantion, 25-27 (1955-1957), pp. 713745). Interestingly, in the 16th chapter of the dialogue Theophanes, Palamas denies the concept which was, in fact, used by Gregory of Nyssa, namely, that only holy people participate in the divine substance, while it cannot be participated in by other beings (see above, the text at the note 4). Palamas attributed this concept to the Messalians and rejected it (Theophanes, 16, in:

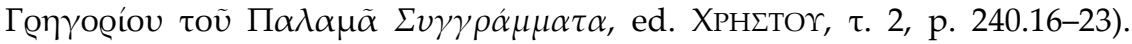
This change of the theological language in Gregory Palamas compared to the language of the pre-Areopagite theology (represented, in particular, by Gregory of Nyssa) is obviously related to the fact that the former theological language in the situation of changed philosophical paradigms entailed unacceptable theological connotations. Thus, for example, at the time of Gregory Palamas the concept of participation in substance referred to the adoption of substance by the participating being or the division of substance (cf. Saint Gregory Palamas, The One Hundred and Fifty Chapters, a critical edition, transl. and study by R. E. SINKEWICZ, C.S.B. (Studies and Texts, 83), Toronto, 1988, Cap. 110, p. 208.1-8), while at the time of Gregory of Nyssa this concept did not have such connotations. 
archically organized kinds of created beings participate in. Palamas' fundamental position was that they participated in the uncreated divine energies, that is, that they naturally participated in the creating energies and supernaturally in the deifying energy. According to Palamas, those energies are God; they are different from the divine substance and differ between each other. We may say that according to the Palamite paradigm, the levels in the hierarchy of naturally participating beings participate in certain universal principles in the Godhead. Yet we have no grounds to think that in the Palamite doctrine these participated principles form a hierarchy between themselves similar to the hierarchy of beings which participated in them.

Among the authors whom we have considered, Dionysius the Areopagite shows a relatively well-developed doctrine of the transcendentals, participated in by the levels of the hierarchy of created beings. The doctrine of the Areopagite implied participation of naturally participating beings, on the one hand, in divine processions, and, on the other hand, in the principles with the prefix "self-." 59 The creating uncreated divine energies in Palamas rather correspond exactly to the processions in the conceptual framework of Dionysius, since the status of the principles with the prefix "self-" in Dionysius is not entirely clear. It may be noted that Dionysius speaks about three of the processions (Being, Life, and Wisdom) with the corresponding five levels in the hierarchy of naturally participating beings (beings living beings - sensible beings - rational beings - intellectual beings), while creative energy in Palamas is correlated with each corresponding level of naturally participating beings.

In this way various aspects of the Patristic understanding of the hierarchy of beings were used and transformed in the teaching of Gregory Palamas.

\section{APPENDIX}

An interesting interpretation of the topic of hierarchy in the Palamite literature can be found in the Poem against Akindynos (second half of 1343), written by the monk David Disypatos, a friend of Gregory Palamas, who similarly to Palamas addressed that topic as an antithesis to the teaching of Akindynos.

The Palamite theme of natural and supernatural participation in the divine energies is formulated in Disypatos in the following way.

(59) De divinis nominibus, 5, 1-3; 5, 5; 11, 6. 
On the one hand, all created beings naturally participate in God through grace (divine energies) as their Creator (participation according to createdness). In this respect, all people participate in GodCreator as rational beings, even those who use their ability of reason in a corrupt way and oppose God. Another way of participation in God - this time not as Creator, but as Father - is possible for those people who purified their intellectual nature; they are enlightened by the divine radiance (energy) which is above reason, and are made by God to be similar to Him. However, none of these modes of participation in God involved participation in the divine substance.

Some terminological difference in the theological language of Disypatos from the language of Palamas is that Disypatos distinguished between participation of all created beings in God as Creator and participation of deified people in God as Father, while Gregory Palamas to the best of my knowledge did not make this distinction in the naming of God as participated in by the created beings in a dual way.

Disypatos shows an interesting interpretation of the hierarchy of beings, different from those discussed above. Whereas similarly to his predecessors, Palamas followed the paradigm which went back to the philosophy of Proclus through Dionysius the Areopagite, implying a limited number of participating natural abilities, the understanding of Disypatos marks a departure from this paradigm. Disypatos thus writes about participation of created beings in God:

But maybe there is a different participation,

Since there is a difference in natures:

There are those which are completely devoid of soul;

There are those which grow on nurture;

There are those which also have the ability to feel,

But lack the ability to move,

Some run, fly, swim,

And we are endowed with the gift of reason.

And we divide again by reason

Each of them infinitely

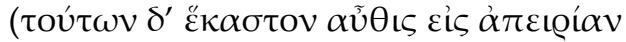

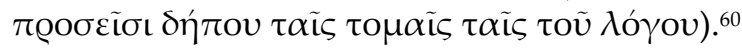

(60) David Disypatos, Poem against Akindynos, ed. BrownING, pp. 465474 . 
Speaking about various natures of created beings, Disypatos mentioned inanimate beings, nourishing beings, motionless sensible beings, sensible beings capable of movement, and rational beings. This list differs from the standard list of levels in the hierarchies of naturally participating created beings, represented in the Patristic authors from Dionysius to Palamas. The list goes back to Aristotle, ${ }^{61}$ but it is possible that in this regard Disypatos also relied on some natural scientific tradition of his time.

In the poem, Disypatos distinguished multiple natural abilities by which created beings could participate in the Creator in His aspect of divine energies. At the end Disypatos said that we could infinitely distinguish such abilities. It is not possible to say with certainty whether this process refers only to the epistemological order as an opportunity to infinitely distinguish in mind more and more differences in created beings, despite the fact that this infinitude of distinctions is not intrinsic for the creation itself, ${ }^{62}$ or, according to Disypatos, this limitlessness may also have an ontological sense as limitlessness of the kinds of beings that exists within nature according to their natural properties.

\section{SUMMARY}

The article traces of how the topic of the hierarchy of the participating beings, given by Dionysius the Areopagite on the basis of the Neoplatonic triad (tetrad) (Goodness) Being, Life, Mind, and, as it is supposed, of the doctrine of the hierarchy of natural beings in Gregory of Nyssa, was developed in the doctrines of Maximus the Confessor, John of Damascus and Gregory Palamas. Three philosophical paradigms of participation in substance, which were used in the Patristic thought, are identified, and the hierarchy of beings is viewed in their context. The traces of

(61) Aristotle, De anima, II, 3, 414a29ff.

(62) Out of Disypatos' contemporaries, such a position was shared by an anti-Palamite Nicephorus Gregoras, who in his treatise On the allencompassing eidos existing in itself which is only contemplated by the mind (ed. H.-V. BEYER, "Nikephoros Gregoras als Theologe und sein erstes Auftreten gegen die Hesychasten," Jahrbuch der Österreichischen Byzantinistik, 20 (1971), p. 183) makes a distinction between the actual limitlessness of God and seeming limitlessness of diverse created world - eidoses and their emanations; the latter, according to Gregoras, are limitless for us, but not according to nature. 
the Neoplatonic triad and tetrad are shown in the writings of Maximus the Confessor. The article analyzes Maximus's treatment of the hierarchy of natural abilities possessed by the created beings, according to which each created being participates in God as well as the problem of what the participated beings are in respect of the participating abilities. John of Damascus's doctrine of the hierarchy of participating beings is viewed, and its dependence on Dionysius the Areopagite is pointed out along with some difference in the nature and the levels of hierarchy in comparison with the hierarchies of Dionysius and Maximus. The reasons for the dissimilarities are discussed. The suggestion concerning the onset of the controversy on the nature of the hierarchy of beings in the Palamite controversy is put forward on the basis of a passage from Disypatos's Short History, discovered by R. Browning. Gregory Palamas's doctrine of the hierarchy of participating beings is analyzed along with its similarities and differences in the levels of hierarchies in respect to Dionysius. It is stated that unlike the previous authors, Gregory treats the topic of hierarchy of participating beings in strict connection with the supernatural participation of created beings in the divinity. It is shown that Gregory of Nyssa and Gregory Palamas used contrasting conceptual frameworks regarding the concepts applied to describing the deifying participation in God in their discussion of the hierarchy of beings. Finally, in the appendix, David Disypatos's teaching on the hierarchy of beings with its specific features is presented. 